CASE REPORT

\title{
HDlive Flow for the Diagnosis of Double Outlet Right Ventricle at 19 Weeks of Gestation
}

\author{
Riko Takayoshi ${ }^{1}$, Toshiyuki Hata ${ }^{2}$, Saori Bouno ${ }^{3}$, Aya Koyanagi $^{4}$, Tomomi Yamanishi ${ }^{5}$, Yuichiro Nakai ${ }^{6}$, Takahito Miyake ${ }^{7}$
}

\begin{abstract}
A BStRACT
We present a case of double outlet right ventricle (DORV) diagnosed prenatally using HDlive Flow with spatiotemporal image correlation (STIC) at 19 weeks of gestation. Bilateral choroid plexus cysts were noted on routine second-trimester screening. Ventricular septal defect, a small pulmonary artery, and parallel arrangement of great arteries were identified using conventional fetal echocardiography and Radiant Flow. HDlive Flow clearly showed a large aorta and small pulmonary artery leaving the right ventricle in parallel. Moreover, abnormal running of the aortic arch and descending aorta was depicted spatially. The diagnosis of DORV was confirmed antenatally. HDlive Flow may be an adjunctive technology to conventional fetal echocardiography for the assessment of normal and abnormal cardiac structures of the fetus in utero.
\end{abstract}

Keywords: 3D/4D fetal echocardiography, Double outlet right ventricle, HDlive Flow, Prenatal diagnosis, Spatiotemporal image correlation. Donald School Journal of Ultrasound in Obstetrics and Gynecology (2020): 10.5005/jp-journals-10009-1673

\section{INTRODUCTION}

HDlive Flow is a novel color/power Doppler technology, which generates three-dimensional (3D)/four-dimensional (4D) reconstructions of normal and abnormal fetal cardiac structures, ${ }^{1-10}$ fetal blood vessels, ${ }^{11-15}$ normal and abnormal placentas, ${ }^{16}$ and gynecologic disorders. ${ }^{17-28}$ There have been only two studies on prenatal 3D color Doppler or HDlive Flow evaluation of double outlet right ventricle (DORV). ${ }^{29,30}$ However, ages at the examination in both cases were after 30 weeks of gestation. Moreover, the image quality of 3D color Doppler in the first case was poor. ${ }^{29}$ In this study, we present a case of DORV diagnosed prenatally using HDlive Flow at 19 weeks of gestation and recommend the use of HDlive Flow for the prenatal diagnosis of congenital heart anomaly.

\section{Case Description}

A 25-year-old pregnant Japanese woman, G (1), P (0), received a routine second-trimester screening at 19 weeks of gestation. Two-dimensional (2D) sonography revealed bilateral choroid plexus cysts. Fetal biometry was consistent with the corresponding gestational age. Two-dimensional fetal echocardiography and Radiant Flow showed a ventricular septal defect, small pulmonary artery, and parallel arrangement of great arteries (Figs 1 to 4). HDlive Flow spatiotemporal image correlation (STIC) (Voluson E10 BT20, GE Healthcare Japan, Tokyo, Japan) clearly demonstrated a large aorta and small pulmonary artery leaving the right ventricle in parallel (Fig. 5). Moreover, abnormal running of the aortic arch and descending aorta was depicted spatially (Fig. 6). The diagnosis of DORV was confirmed antenatally.

The patient and her husband desired to discontinue the pregnancy, and so abortion was induced at 21 weeks and 1 day of pregnancy, resulting in a male abortus weighing $349 \mathrm{~g}$. The parents refused further workup, such as, autopsy and chromosomal analysis of the baby despite intensive counseling.

\section{Discussion}

Conventional 2D sonographic characteristics of DORV are transposed parallel great vessels both arising from the right ventricle, ${ }^{31}$ and the
1,3-5 Department of Obstetrics and Gynecology, Miyake Clinic, Ofuku, Minami-ku, Okayama, Japan

2,7Department of Obstetrics and Gynecology, Miyake Clinic, Ofuku, Minami-ku, Okayama, Japan; Department of Perinatology and Gynecology, Kagawa University Graduate School of Medicine, Ikenobe, Miki, Kagawa, Japan

${ }^{6}$ Department of Obstetrics and Gynecology, Kawasaki Medical School, Matsushima, Kurashiki, Okayama, Japan

Corresponding Author: Toshiyuki Hata, Department of Obstetrics and Gynecology, Miyake Clinic, Ofuku, Minami-ku, Okayama, Japan; Department of Perinatology and Gynecology, Kagawa University Graduate School of Medicine, Ikenobe, Miki, Kagawa, Japan, Phone: +81-(0)87-891-2174, e-mail: toshi28@med.kagawa-u.ac.jp

How to cite this article: Takayoshi R, Hata T, Bouno $S$, et al. HDlive Flow for the Diagnosis of Double Outlet Right Ventricle at 19 Weeks of Gestation. Donald School J Ultrasound Obstet Gynecol 2020;14(4): 351-354.

Source of support: Nil

Conflict of interest: None

aorta is displaced anteriorly and more to the right than normal on a three-vessel view. ${ }^{32}$ However, it is very difficult to differentiate DORV from other conotruncal abnormalities, especially tetralogy of Fallot. ${ }^{31}$ In the current case, the antenatal diagnosis of DORV was suspected by conventional fetal echocardiography. HDlive Flow provided additional useful information on the antenatal diagnosis of DORV. Its unique characteristics are spatially transposed parallel great vessels both arising from the right ventricle, and abnormal running of the aortic arch and descending aorta. In the normal fetal heart, criss-cross arrangements of the pulmonary artery from the right ventricle and aorta from the left ventricle are evident (Fig. 7). The 3D/4D shape of DORV using HDlive Flow is completely different from that of the normal fetal heart. HDlive Flow in fetal echocardiography may facilitate a greater understanding of the complex cardiac morphology, such as, DORV and more accurate prenatal diagnosis. Moreover, this technique may lead to a

() The Author(s). 2020 Open Access This article is distributed under the terms of the Creative Commons Attribution 4.0 International License (https://creativecommons. org/licenses/by-nc/4.0/), which permits unrestricted use, distribution, and non-commercial reproduction in any medium, provided you give appropriate credit to the original author(s) and the source, provide a link to the Creative Commons license, and indicate if changes were made. The Creative Commons Public Domain Dedication waiver (http://creativecommons.org/publicdomain/zero/1.0/) applies to the data made available in this article, unless otherwise stated. 


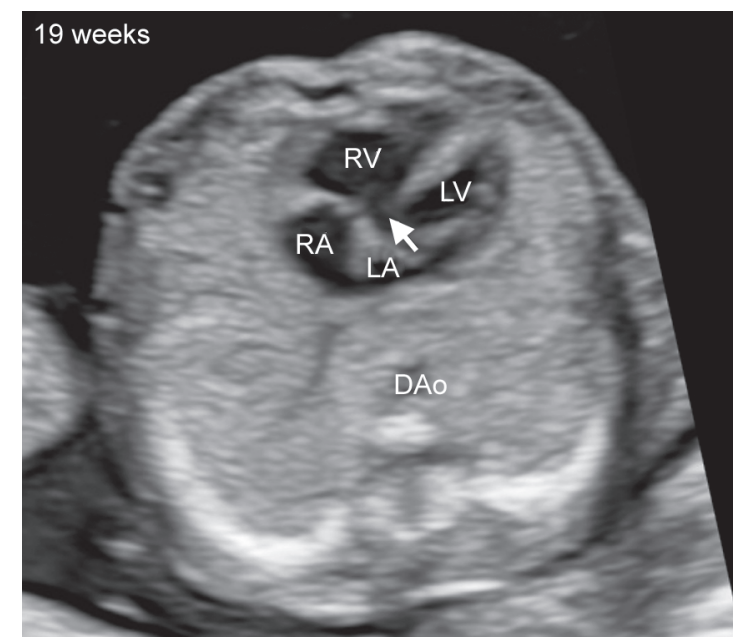

Fig. 1: Four-chamber view of double outlet right ventricle at 19 weeks of gestation. Ventricular septal defect (arrow) is noted. DAo, descending aorta; $L A$, left atrium; LV, left ventricle; $R A$, right atrium; $R V$, right ventricle

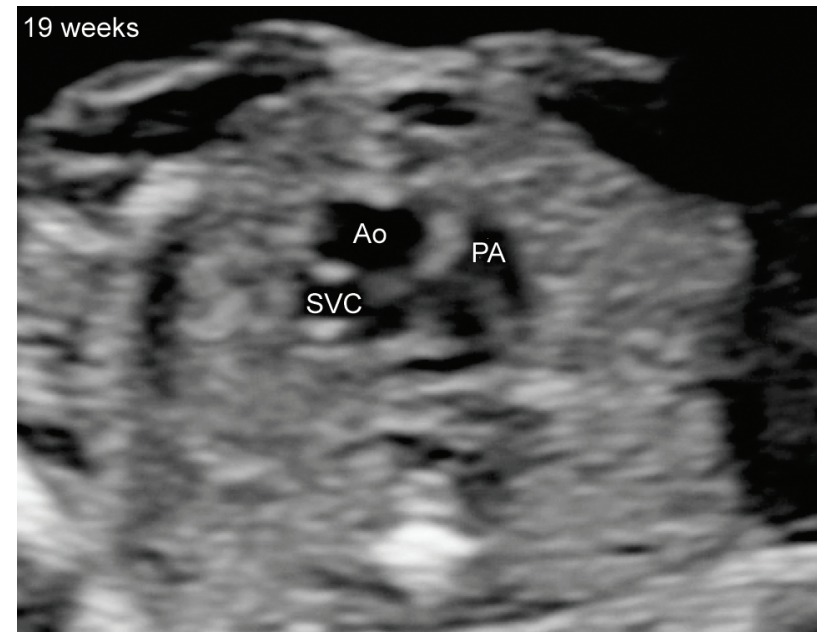

Fig. 3: Three-vessel view of double outlet right ventricle at 19 weeks of gestation. Ao, aorta; PA, pulmonary artery; SVC, superior vena cava

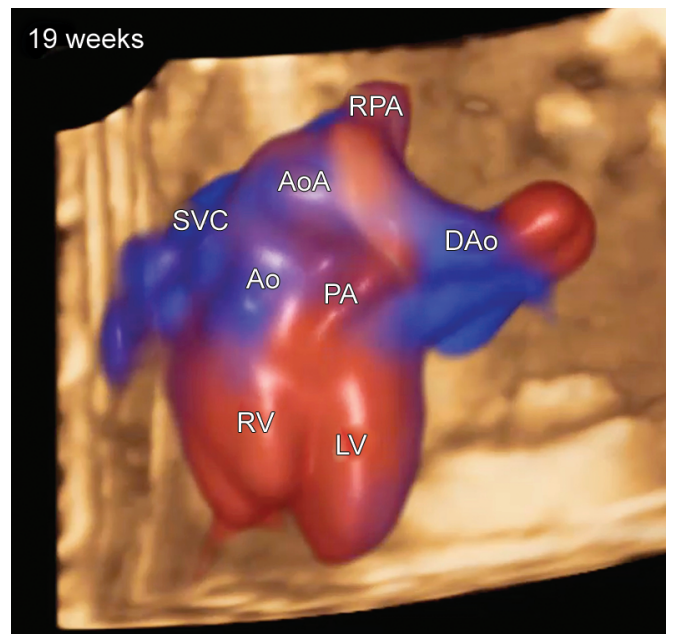

Fig. 5: HDlive Flow image of double outlet right ventricle (spatial three-vessel view) at 19 weeks of gestation. The parallel arrangement of great arteries is clearly recognized. Ao, aorta; AoA, aortic arch; DAo, descending aorta; LV, left ventricle; PA, pulmonary artery; RPA, right pulmonary artery; RV, right ventricle; SVC, superior vena cava

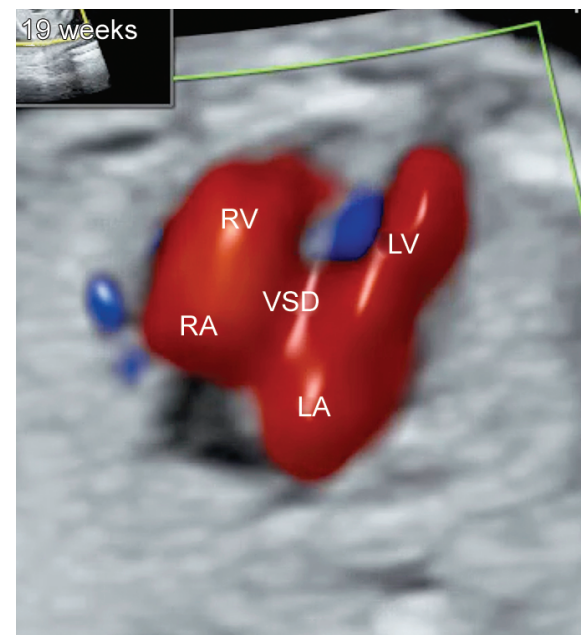

Fig. 2: Four-chamber view of double outlet right ventricle at 19 weeks of gestation using Radiant Flow. LA, left atrium; LV, left ventricle; RA, right atrium; RV, right ventricle; VSD, ventricular septal defect

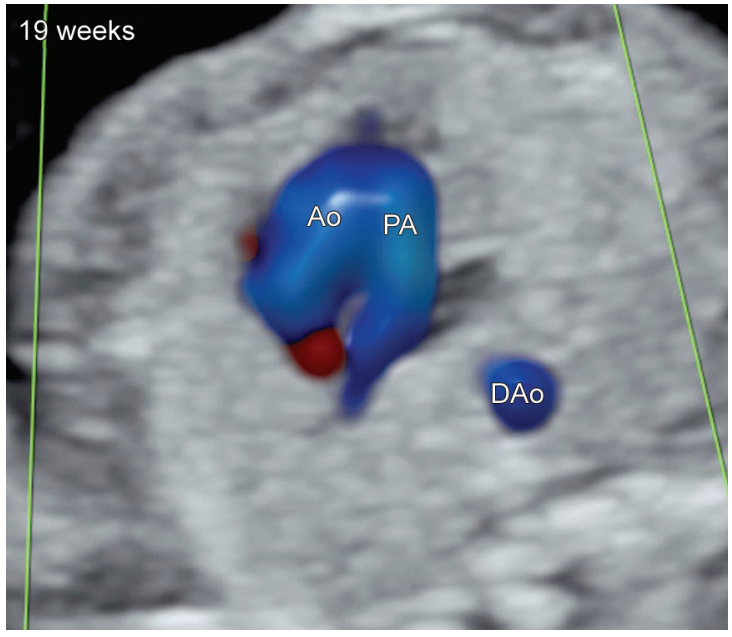

Fig. 4: Parallel arrangement of great arteries in case of double outlet right ventricle at 19 weeks of gestation using Radiant Flow. Ao, aorta; DAo, descending aorta; PA, pulmonary artery

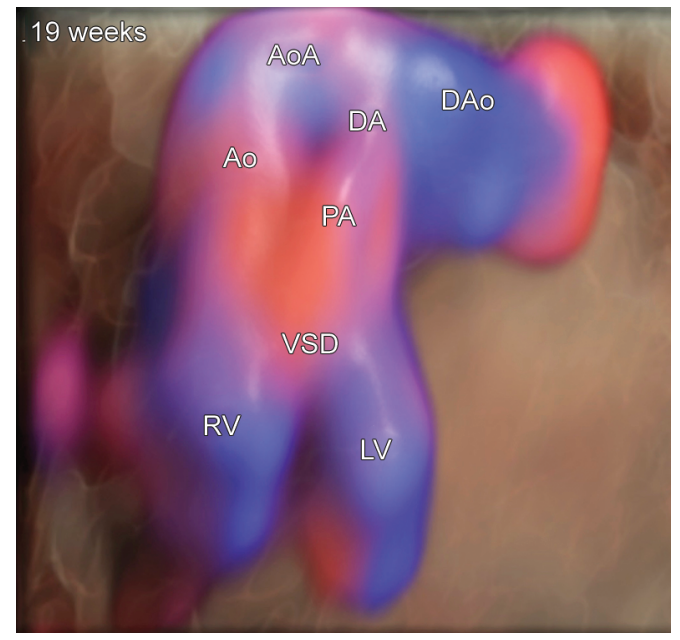

Fig. 6: HDlive Flow Silhouette image of double outlet right ventricle (spatial three-vessel view) at 19 weeks of gestation. The parallel arrangement of great arteries is clearly shown. Ao, aorta; AoA, aortic arch; DA, ductus arteriosus; DAo, descending aorta; LV, left ventricle; $\mathrm{PA}$, pulmonary artery; RV, right ventricle; VSD, ventricular septal defect 


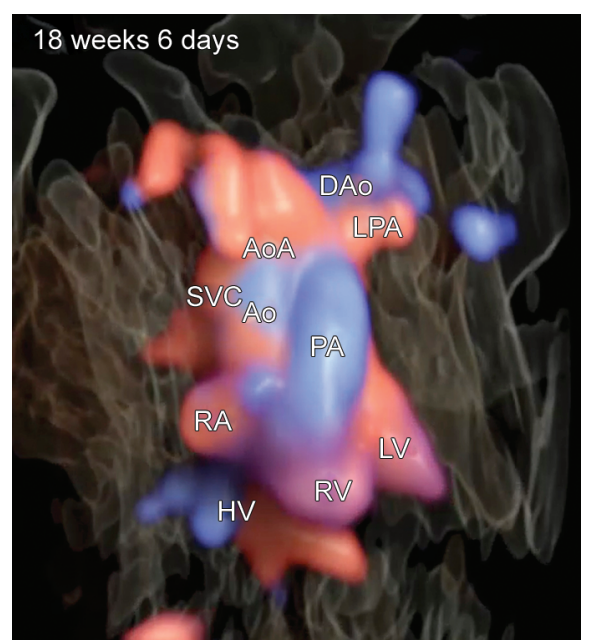

Fig. 7: HDlive Flow image of the normal fetal heart (spatial three-vessel view) at 18 weeks and 6 days of gestation. The criss-cross arrangement of great arteries is clearly recognized. Ao, aorta; AoA, aortic arch; DAo, descending aorta; HV, hepatic vein; LPA, left pulmonary artery; LV, left ventricle; $\mathrm{PA}$, pulmonary artery; $\mathrm{RA}$, right atrium; $\mathrm{RV}$, right ventricle; SVC, superior vena cava

better understanding of complex congenital heart anomalies for beginners or sonographers unfamiliar with fetal echocardiography.

\section{References}

1. AboEllail MAM, Kanenishi K, Tenkumo C, et al. Diagnosis of truncus arteriosus in first trimester of pregnancy using transvaginal fourdimensional color Doppler ultrasound. Ultrasound Obstet Gynecol 2015;45(6):759-760. DOI: 10.1002/uog.14868.

2. AboEllail MAM, Kanenishi K, Tenkumo $C$, et al. Four-dimensional power Doppler sonography with the HDlive silhouette mode in antenatal diagnosis of a right aortic arch with an aberrant left subclavian artery. JUltrasound Med 2016;35(3):661-663. DOI: 10.7863/ ultra.15.05047.

3. Yang PY, Sajapala S, Yamamoto K, et al. Antenatal diagnosis of idiopathic dilatation of fetal pulmonary artery with 3D power Doppler imaging. J Clin Ultrasound 2017;45(2):121-123. DOI: 10.1002/jcu.22367.

4. Ito M, AboEllail MAM, Yamamoto K, et al. HDlive flow silhouette mode and spatiotemporal image correlation for diagnosing congenital heart disease. Ultrasound Obstet Gynecol 2017;50(3):411-415. DOI: 10.1002/uog.17519.

5. Hata T, Ito M, Nitta E, et al. HDlive flow silhouette mode for diagnosis of ectopia cordis with a left ventricular diverticulum at 15 weeks' gestation. J Ultrasound Med 2018;37(10):2465-2467. DOI: 10.1002/ jum.14583.

6. Karmegaraj B, Rajeshkannan R, Kappanayil M, et al. Fetal descending aortic tortuosity with ductal aneurysm. Ultrasound Obstet Gynecol 2019;54(1):142-144. DOI: 10.1002/uog.20303.

7. Hata T, Hanaoka U, Kanenishi K. HDliveFlow silhouette mode for fetal heart Merz E, Kurjak A, ed. Donald School Textbook Current Status of Clinical Use of 3D/4D Ultrasound in Obstetrics and Gynecology. New Delhi: Jaypee Brothers Medical Publishers (P) Ltd.; 2018. pp. 137-151.

8. Hata T. HDliveFlow for fetal heart Sen C, Stanojevic M, ed. Fetal Heart: Screening, Diagnosis and Intervention. New Delhi: Jaypee Brothers Medical Publishers (P) Ltd.; 2019. pp. 201-217.

9. Hata T, Koyanagi A, Yamanishi T, et al. Success rate of five cardiac views using HDlive flow with spatiotemporal image correlation at 18-21 and 28-31 weeks of gestation. J Perinat Med 2020;48(4):384-388. DOI: 10.1515/jpm-2019-0434.
10. Hata T, Koyanagi A, Yamanishi T, et al. HDlive flow for diagnosis of persistent left superior vena cava with absent right superior vena cava. Donald School J Ultrasound Obstet Gynecol 2020. in press.

11. Tenkumo C, Hanaoka U, AboEllail MAM, et al. HDlive flow with HDlive silhouette mode in diagnosis of fetal hepatic hemangioma. Ultrasound Obstet Gynecol 2017;49(4):540-545. DOI: 10.1002/ uog. 16215.

12. Hata T, Takayoshi R, Miyake T, et al. HDlive flow with STIC for assessment of fetal goiter. Donald School J Ultrasound Obstet Gynecol 2020;14(1):1-3. DOI: 10.5005/jp-journals-10009-1616.

13. Hata T, Koyanagi A, Yamanishi T, et al. Fetal intra-abdominal umbilical vein varix assessed by novel Doppler ultrasound. Donald School J Ultrasound Obstet Gynecol 2020. in press.

14. Ganjiguur TO, AboEllail MAM, Mori N, et al. HDliveFlow with HDlive silhouette mode for diagnosis of persistent right umbilical vein and single umbilical artery. Donald School J Ultrasound Obstet Gynecol 2018;12(1):1-3. DOI: 10.5005/jp-journals-10009-1545.

15. Hata $T$, Kanenishi $K$, Ishibashi $M$, et al. HDliveFlow with HDlive silhouette mode for diagnosis of fetal diaphragmatic eventration. Donald School J Ultrasound Obstet Gynecol 2018;12(3):149-152. DOI: 10.5005/jp-journals-10009-1565.

16. Yang PY, Kanenishi K, Ishibashi M, et al. HDliveFlow with HDlive silhouette mode in antenatal diagnosis of bilobed placenta. Donald School JUltrasound Obstet Gynecol 2016;10(4):415-417. DOI: 10.5005/ jp-journals-10009-1495.

17. Sajapala S, AboEllail MAM, Tanaka T, et al. Three-dimensional power Doppler with silhouette mode for diagnosis of malignant ovarian tumors. Ultrasound Obstet Gynecol 2016;48(6):806-808. DOI: 10.1002/uog.15730.

18. Yamamoto $K$, AboEllail MAM, Ito $M$, et al. HDlive imaging in diagnosis of uterine artery pseudoaneurysm during pregnancy. Ultrasound Obstet Gynecol 2016;48(1):125-128. DOI: 10.1002/uog.15802.

19. AboEllail MAM, Ishimura M, Sajapala S, et al. Three-dimensional color/ power Doppler sonography and HDlive silhouette mode for diagnosis of molar pregnancy. J Ultrasound Med 2016;35(9):2049-2052. DOI: 10.7863/ultra.15.11070.

20. Tanaka T, AboEllail MAM, Ishimura M, et al. HDliveFlow with HDlive silhouette mode for diagnosis of malignant tumors of uterine cervix. Donald School J Ultrasound Obstet Gynecol 2016;10(4):409-412. DOI: 10.5005/jp-journals-10009-1493.

21. Yamamoto K, AboEllail MAM, Ishimura M, et al. HDlive silhouette inversion mode in diagnosis of complete hydatidiform mole. J Ultrasound Med 2017;36(4):833-835. DOI: 10.7863/ultra.16.05066.

22. Hata T, Kanenishi K, Tanaka T, et al. HDliveFlow silhouette mode for the diagnosis of uterine sarcoma. Donald School J Ultrasound Obstet Gynecol 2017;11(4):259-260. DOI: 10.5005/jp-journals-10009-1530.

23. Tenkumo C, Kanenishi K, AboEllail MAM, et al. HDliveFlow silhouette mode for the diagnosis of uterine enhanced myometrial vascularity/ arteriovenous malformations. J Med Ultrasonics 2018;45(2):349-352. DOI: 10.1007/s10396-017-0823-4.

24. Tenkumo C, Hanaoka U, Kanenishi K, et al. HDliveFlow silhouette mode with HDlive sihlouette mode for diagnosis of sclerosing stromal tumor of the ovary. Donald School J Ultrasound Obstet Gynecol 2018;12(2):85-88. DOI: 10.5005/jp-journals-10009-1555.

25. Hata T, Kanenishi K, Nitta E, et al. HDliveFlow silhouette mode with HDlive silhouette mode for diagnosis of molar pregnancy. Ultrasound Obstet Gynecol 2018;52(4):552-554. DOI: 10.1002/uog.19106.

26. Yamashita $T$, Tenkumo $C$, Ishibashi $M$, et al. HDlive flow for diagnosis of invasive mole. Donald School J Ultrasound Obstet Gynecol 2019;13(1):1-3. DOI: 10.5005/jp-journals-10009-1579.

27. Tanaka T, Kanenishi K, Yamashita T, et al. HDlive flow silhouette mode for assessment of tumor vascularity in advanced cervical cancer. Donald School J Ultrasound Obstet Gynecol 2019;13(3):110-112. DOI: 10.5005/jp-journals-10009-1597.

28. Hata T, Mori N, Yamamoto K, et al. HDlive flow silhouette with glassbody rendering mode for diagnosis of tubal serous borderline tumor. 
Donald School J Ultrasound Obstet Gynecol 2019;13(3):153-154. DOI: 10.5005/jp-journals-10009-1599.

29. Hata T, Kanenishi K, Mori N, et al. Four-dimensional color Doppler reconstruction of the fetal heart with glass-body rendering mode. Am J Cardiol 2014;114(10):1603-1606. DOI: 10.1016/j.amjcard.2014.08.025.

30. Hata T, Mori N, AboEllail MAM, et al. Advances in color Doppler in obstetrics. J South Asian Feder Obst Gynae 2019;11(1):1-12. DOI: 10.5005/jp-journals-10006-1641.
31. Smith RS, Comstock CH, Kirk JS, et al. Double-outlet right ventricle: an antenatal diagnostic dilemma. Ultrasound Obstet Gynecol 1999;14(5):315-319. DOI: 10.1046/j.1469-0705.1999. 14050315.x.

32. Vinals F, Heredia F, Giuliano A. The role of the three vessels and trachea view (3VT) in the diagnosis of congenital heart defects. Ultrasound Obstet Gynecol 2003;22(4):358-367. DOI: 10.1002/ uog.882. 